Published by LPMP Imperium

Journal homepage: https:/ / ejournal.imperiuminstitute.org/ index.php/ AKURASI

\title{
DETERMINAN MANEJEMEN LABA: PERAN LIABILITAS PAJAK TANGGUHAN DAN LEVERAGE
}

\author{
Eky Septiawan', Yohan H. Wibowo' ${ }^{1}$, Hendryadi2* \\ ${ }^{1}$ Fakultas Ekonomi Universitas Islam Attahiriyah, Jakarta, Indonesia \\ ${ }^{2}$ Sekolah Tinggi Ilmu Ekonomi Indonesia Jakarta, Jakarta, Indonesia
}

AKURASI

95

Paper type

Accounting and finance, Research paper

Received: 23 Jun 2020

Revised: 07 Jul 2020

Accepted: 08 Jul 2020

Online: 08 Jul 2020

Keywords: Deferred Tax Liabilities, Leverage, Earnings Management

Akurasi: Jurnal Riset Akuntansi dan Keuangan, Vol 2, No.2, Agustus 2020, pp. 95 - 102

eISSN: 2685-2888

PETERMINAN MANEJEMEN LABA: PERAN LIABILITAS PAJAK TANGGUHAN DAN LEVERAGE. AKURASI: Jurnal Riset Akuntansi Dan Keuangan, 2(2), 95 104.. DOI: https:/ / doi.org/ 10.36407/ akurasi.v2i2.193 


\section{PENDAHULUAN}

Laporan keuangan yang disajikan baik dan akurat dapat memberikan gambaran keadaan yang nyata megenai kondisi perusahaan dan prestasi yang sudah diraih oleh perusahaan dalam periode tertentu. Kondisi ini secara umum digunakan untuk menilai kinerja keuangan baik oleh pihak internal maupun eksternal.pada laporan keuangan, Laba merupakan komponen utama yang selalu menjadi perhatian berbagai pihak untuk menentukan baik tidaknya sebuah perusahaan menjalankan bisnisnya. Laba yang tinggi menggambarkan bahwa bahwa bisnis berjalan dengan baik sehingga menghasilkan pendapatan, laba, dan arus kas. Strategisnya pelaporan laba ini menjadikan banyak perusahaan melakukan strategi intervensi untuk memperoleh keuntungan pribadi. Konsep ini dikenal sebagai manajemen laba (Wang, 2016).

Manajemen laba merupakan salah satu topik penting dalam kajian akuntansi dan keuangan dalam dua dekade terakhir. Schipper (Wang, 2016) menjelaskan bahwa manajemen laba sebagai intervensi yang disengaja dalam proses pelaporan keuangan yang dilakukan perusahaan dengan maksud memperoleh beberapa keuntungan pribadi. Kondisi ini juga dapat dinyatakan sebagai manipulasi aktif dari laba, dan lebih lanjut oleh Walker (Wang, 2016) disebut sebagai penggunaan kebijaksanaan manajerial (dalam GAAP) atas pilihan akuntansi, pilihan pelaporan laba, dan keputusan ekonomi nyata untuk mempengaruhi bagaimana peristiwa ekonomi dapat tercermin dalam satu atau lebih ukuran pendapatan. Penyalahgunaan seperti manajemen laba terjadi ketika orang mengambil keuntungan dari fleksibilitas yang melekat dalam penerapan GAAP dengan tujuan mengaburkan volatilitas keuangan aktual, dan pada gilirannya akan menyembunyikan konsekuensi sebenarnya dari keputusan manajemen (Levitt, 1998, dalam Widarti \& Pramajaya, 2018).

Manajer menyalahgunakan fleksibilitas yang diberikan oleh prinsip akuntansi dan dengan sengaja dengan cara mengubah isi informasi dalam laporan keuangan untuk keuntungan pribadi yang menyesatkan pengguna laporan. Perilaku manajer oportunistik dapat terjadi karena mekanisme kontrol perusahaan yang lemah. Kasus-kasus pelanggaran pelaporan keuangan oleh perusahaan publik yang ditangani oleh Bapepam sebagian besar melibatkan pelanggaran prinsip-prinsip ekspresi yang akurat dan transparan, ini akan sangat merugikan bagi pengguna laporan keuangan, terutama investor, karena informasi yang dipublikasikan oleh perusahaan yang mengandung kesalahan telah menjadi dasar dari investasi keputusan. Ketika kesalahan informasi yang dipublikasikan diumumkan, harga saham turun dan investor akan beralih ke perusahaan lainnya (Widarti \& Pramajaya, 2018).

Para peneliti telah berupaya untuk memahami bagaimana dan apa faktor yang mempengaruhi perilaku manajemen laba, diantaranya adalah pajak (Susanto, Pirzada, \& Adrianne, 2019; Mulatsih, Dharmayanti, \& Ratnasari, 2019; Widiatmoko \& Mayangsari, 2016; Ari \& Sugeng, 2015; Ardi, 2014; Thomas, 2015), leverage (Susanto, Pirzada, \& Adrianne, 2019; Sutadipraja et al., 2019; Octaviani \& Kartikaningdyah, 2019; Widiatmoko \& Mayangsari, 2016). Menurut penelitian Ari dan Sugeng (2015), Ardi (2014), dan Thomas (2015) liabilitas pajak tangguhan berpengaruh terhadap pendektesian manajemen laba, sedangkan penelitian Jadiba et al. (2013) dan Lucy (2016) memiliki kesimpulan berbeda dimana liabilitas pajak dinyatakan tidak memiliki efek terhadap manajemen laba. Menggunakan konsep yang berbeda, Susanto et al. (2019) memberikan kesimpulan bahwa agresivitas pajak berpengaruh terhadap manajemen laba. Mulatsih et al. (2019) menguji hubungan rencana pajak, asset pajak tangguhan, dan beban pajak tangguhan, dan temuan mereka hanya berhasil membuktikan perencanaan pajak sebagai determinan manajemen laba. Kontradiksi pada hubungan liabilitas pajak, maupun konsep pajak lainnya dalam mempengaruhi manajemen pajak masih memberikan peluang pembuktian ulang untuk memperoleh bukti empiris terbaru.

Selain pajak, faktor lain yang juga banyak dikaitkan dengan manajemen laba adalah leverage. Studi yang dilakukan oleh Kustini dan Ekawati dalam Agusianto (2014) menyatakan bahwa perusahaan yang memiliki tingkat rasio yang tinggi mempunyai risiko yang tinggi pula, maka laba akan berfluktuasi sehingga perusahaaan memiliki kecenderungn untuk melakukan intervensi / manajemen laba sehingga laba terlihat stabil. Susanto et al. (2019) dan Sutadipraja et al. (2019) dalam studi mereka memberikan 
kesimpulan bahwa leverage memiliki efek signifikan pada manajemen laba, sedangkan Octaviani dan Kartikaningdyah (2019) tidak berhasil membuktikan pengaruh leverage pada manajemen laba,

Masih banyanya pertentangan mengenai determinan manajemen laba menjadi motivasi utama penelitian ini. Dengan demikian, studi yang dilakukan sekarang bertujuan untuk mengetahui pengaruh liabilitas pajak dan leverage pada manajemen laba. Penelitian ini dapat berkontribusi untuk memperkaya kajian mengenai faktor yang mempengaruhi manajemen laba, sekaligus sebagai informasi yang bermanfaat bagi investor untuk mengambil keputusan investasi.

\section{KAJIAN PUSTAKA}

Penelitian ini menggunakan Agency Theory dan Signaling Theory sebagai kerangka kerja untuk menjelaskan hubungan antar variabel. Jensen dan Meckling (1976) teori agensi adalah teori yang menggambarkan konflik agensi yang terjadi antara dua pihak, yaitu agen dan pelaku karena perbedaan kepentingan antara keduanya. Prinsipal mendelegasikan wewenang pengambilan keputusan kepada agen. Karena banyak keputusan yang memengaruhi prinsipal secara finansial dibuat oleh agen, perbedaan pendapat, dan bahkan perbedaan dalam prioritas dan kepentingan, dapat muncul. Teori agensi mengasumsikan bahwa kepentingan prinsipal dan agen tidak selalu sejalan. Ini kadang-kadang disebut sebagai masalah prinsipal-agen. Menurut definisi, agen menggunakan sumber daya prinsipal. Prinsipal telah mempercayakan uang tetapi memiliki sedikit atau tidak memiliki informasi yang dapat dimonitor setiap hari. Agen adalah pembuat keputusan tetapi menimbulkan risiko kecil atau tidak sama sekali karena kerugian akan ditanggung oleh principal.

Tata kelola perusahaan dapat digunakan untuk mengubah aturan di mana agen beroperasi dan mengembalikan kepentingan prinsipal. Agen harus memiliki insentif yang mendorong mereka untuk bertindak bersama dengan kepentingan prinsipal. Teori agensi dapat digunakan untuk merancang insentif ini secara tepat dengan mempertimbangkan kepentingan apa yang memotivasi agen untuk bertindak. Insentif yang mendorong perilaku yang salah harus dihilangkan, dan aturan yang mencegah moral hazard harus ada. Memahami mekanisme yang menciptakan masalah membantu bisnis mengembangkan kebijakan perusahaan yang lebih baik.

Teori pensinyalan membantu para peneliti dan manajer lebih memahami komunikasi dalam kondisi informasi yang tidak sempurna. Sinyal adalah tindakan atau pernyataan yang menyampaikan kemampuan atau niat seseorang atau perusahaan dan mengungkapkan berbagai informasi. Teori pensinyalan mengemukakan pemilik modal yang rasional mengharapkan perusahaan untuk menghormati komitmennya karena potensi hukuman ekonomi melalui penghentian investasi. (Whelan \& Demangeot, 2015).

\section{Manajemen Laba}

Sulistyanto (2014:6) mendefinisikan manajemen laba sebagai "upaya manajer perusahaan untuk mengintervensi atau mempengaruhi informasi-informasi dalam laporan keuangan dengan tujuan untuk mengelabui stakeholder yang ingin mengetahui kinerja dan kondisi perusahaan". Manajemen laba adalah kegiatan manajerial untuk mempengaruhi laporan keuangan dengan memanipulasi data keuangan atau pemilihan informasi metode dan prosedur akuntansi yang secara umum diterima dan diakui yang bertujuan untuk mendapatkan keuntungan perusahaan (Sulistyanto, 2014). Ada dua teori yang mendasari munculnya praktik manajemen pembelajaran, yaitu: teori keagenan dan teori akuntansi positif (Mulatsih et al., 2019). Dapat dinyatakan bahwa manajemen laba merupakan suatu tindakan yang dilakukan oleh manajer atau pembuat laporan keuangan dengan cara memanipulasi data atau informasi akuntansi agar jumlah laba yang tercatat dalam laporan keuangan untuk memperoleh tujuan tertentu. 


\section{Liabilitas pajak tangguhan dan manajemen laba}

Liabilitas pajak tangguhan suatu perusahaan meningkat ketika pelaporan laba komersilnyalebih tinggi dibandingkan dengan laba menurut pajak. Liabilitas pajak tangguhan dihitung dengan mengalikan jumlah perbedaan temporer dengan tarif pajak. Semakin besar persentase deferred tax liabilities terhadap total beban pajak perusahaan menunjukkan standar akuntansi yang semakin liberal Yulianti (2004) dalam Anasta (2015). Hal tersebut dapat dikaitan dengan salah satu motivasi manajer melakukan manajemen laba yaitu bonus scheme dengan membesarkan atau mengecilkan jumlah beban pajak tangguhan yang diakui dalam laporan laba rugi akibat dari perbedaan antara laba akuntansi dengan laba fiskal yang memiliki hubungan positif dengan insentif pelaporan keuangan seperti pemberian bonus (dalam Sutadipraja et al., 2019). Berdasarkan PSAK No.46, Selisih antara Beban Pajak kini dan dan beban pajak komersil adalah Beban Pajak Tangguhan. Junery (2016); Sutadipraja et al., 2019 dalam penelitiannya mampu membuktikan bahwa beban pajak tangguhan memiliki pengaruh terhadap manajemen laba.

$\mathrm{H}_{1}$ : liabilitas pajak tangguhan berpengaruh signifikan terhadap manajemen laba

\section{Leverage dan manajemen laba}

Leverage adalah penggunaan hutang (modal pinjaman) untuk melakukan investasi atau proyek. Hasilnya adalah melipatgandakan potensi pengembalian dari suatu proyek. Pada saat yang sama, leverage juga akan menggandakan potensi risiko turun jika investasi tidak berjalan dengan baik. Konsep leverage digunakan oleh investor dan perusahaan. Investor menggunakan leverage untuk secara signifikan meningkatkan pengembalian yang dapat diberikan pada investasi. Mereka meningkatkan investasi mereka dengan menggunakan berbagai instrumen, termasuk opsi, futures, dan margin account. Perusahaan dapat menggunakan leverage untuk membiayai aset mereka. Dengan kata lain, dibandingkan dengan menerbitkan saham untuk meningkatkan modal, perusahaan dapat menggunakan pembiayaan utang untuk berinvestasi dalam operasi bisnis dalam upaya meningkatkan nilai pemegang saham. Susanto et al. (2019) dan Sutadipraja et al. (2019) dalam studi mereka memberikan kesimpulan bahwa leverage memiliki efek signifikan pada manajemen laba.

$\mathrm{H}_{2}$ : leverage berpengaruh signifikan terhadap manajemen laba

\section{METODE PENELITIAN}

Objek penelitian ini adalah manajemen laba dan faktor-faktor yang mempengaruhinya, yaitu Asimetri informasi, liabilitas pajak tangguhan, dan leverage.Periode pengamatan yang diambil dalam penelitian ini adalah mulai tahun 2014 sampai dengan 2018. Dalam penelitian ini menggunakan jenis penelitian data kuantitatif.Data kuantitatif yaitu data dalam bentuk angka. Desain penelitian ini adalah analisa data sekunder, yaitu suatu penelitian yang bertujuan untuk mengetahui asimetri informasi, liabilitas pajak tangguhan, leverage terhadap manajemen laba di perusahaan LQ45 yang terdaftar dalam Bursa Efek Indonesia.

\section{Populasi dan Sampel}

Populasi dalam penelitian ini adalah perusahaan LQ45 yang terdaftar di Bursa Efek Indonesia tahun 2014-2018 sebanyak 45 perusahaan. Pengambilan sampel dilakukan dengan menggunakan metode purpose sampling dengan tujuan mendapatkan sampel yang representative sesuai dengan kriteria yang di tentukan. Teknik pengumpulan data merupakan suatu proses mengumpulkan data yang diperlukan dalam penelitian, dengan data yang terkumpul untuk menguji hipotesis yang telah dirumuskan. Analisis data yang dilakukan oleh penelitian ini adalah dengan menggunakan data sekunder yang berupa laporan keuangan perusahaan-perusahaan LQ45 yang terdaftar di Bursa Efek Indonesia (BEI). 


\section{Definisi Operasional Variabel dan Pengukuran}

Manajemen laba di ukur menggunakan discretionary accruals (DA), Liabilitas pajak tangguhan pada penelitian ini diperoleh dari liabilitas pajak tangguhan pada periode laporan keuangan dibagi dengan total aset pada peride sebelumnya. Leverage atau pada umumnya disebut Debt To Asset Ratio mengukur persentase dana yang disediakan oleh kreditur, diukur dengan rasio antara total hutang dengan total aset.

\section{Model Regresi Data Panel}

Pemilihan data panel dikarenakan dalam penelitian ini menggunakan data time series dan data cross section. Penggunaan data time series dalam penelitian ini, yakni tahun 2014-2018. Sedangkan penggunaan data cross section dalam penelitian ini, yakni perusahaan yang masuk kedalam indeks LQ45 di Bursa Efek Indonesia, dengan total sampel perusahaan 11 perusahaan

\section{HASIL DAN PEMBAHASAN}

\section{Statistik deskriptif}

Analisis dtatistik seskriptif memberikan gambaran atau deskripsi suatu data yang dilihat dari nilai minimum, maksimum, rata-rata (mean), dan standar deviasi masing-masing variabel penelitian. Analisis ini bertujuan untuk menjelaskan nilai rata-rata (mean) dan standar deviasi antara variabel independen, yaitu: liabilitas pajak tangguhan, dan leverage terhadap variabel dependen yaitu manajemen laba yang diproksikan melalui discretionary accrual

\section{Tabel 1. Deskriptif statistik}

\begin{tabular}{lllll}
\hline & Min & Max & Mean & Std. Dev \\
\hline LPP & -0.262 & 0.431 & -0.0127 & 0.0942 \\
LEV & 0.0023 & 0.0574 & 0.0325 & 0.0133 \\
EM & -0.0458 & 0.0809 & 0.0261 & 0.0245 \\
\hline
\end{tabular}

Keterangan: LPP: liabilitas pajak tangguhan; LEV: leverage; EM: earning management

Liabilitas pajak tangguhan dengan nilai rata-rata 0,0142 menunjukkan bahwa tingkat liabilitas pajak tangguhan yang terjadi di perusahaan manufaktur relatif rendah. Manajemen laba dengan nilai rata-rata 0,00261 menunjukkan bahwa praktik manajemen yang dilakukan oleh data sampel cukup rendah. Nilai discretionary accrual yang bernilai positif dan negatif menunjukkan bahwa terdapat DA yang menaikkan laba (income increasing) dan menurunkan laba (income decreasing).

\section{Uji hipotesis}

Analisis ini digunakan untuk menjawab rumusan masalah yaitu mengetahui seberapa liabilitas pajak tangguhan dan leverage perusahaan terhadap manajemen laba dilakukan dengan model regresi data panel yang menggunakan aplikasi Eviews 10. Fixed effect model (FEM) dipilih dalam penelitian berdasarkan hasil uji chow dan uji Hausman, yang keduanya menghasilkan kesimpulan yang serupa. Berikut ini ditampilkan hasil regresi data panel yang diperoleh berdasarkan data yang dianalisis: 
Tabel 2. Regresi data panel

\begin{tabular}{llll}
\hline & Koefisien & t-value & Sig \\
\hline LPP & -.0042 & -0.176 & 0.861 \\
LEV & 0.243 & 2.242 & 0.03 \\
Fstatistics & 4.753 & & \\
Sig & 0.002 & & \\
Adj. R Square & 0.535 & & \\
\hline
\end{tabular}

Sumber: data lapangan, diolah. LPP: liabilitas pajak tangguhan; LEV: leverage

\section{Goodness of Fit Test dan koefisien determinasi}

Uji F dilakukan untuk menguji kecocokan model (goodness of fit) yaitu apakah model dapat diinterpretasi lebih lanjut. Hasil uji menunjukkan nilai probability pada F sebesar $0.002(<0.05)$ sehingga dapat dinyatakan bahwa model regresi sudah memenuhi keoccokan model yang baik. Nilai adj. $\mathrm{R} 2$ dalah 0,535 . Nilai ini dapat diartikan bahwa kemampuan model menjelaskan variasi manajemen laba sebesar 53.5\%, dan sisanya dipengaruhi oleh faktor lain.

Hipotesis 1 . Berdasarkan uji t diperoleh $t_{\text {hitung }}$ liabilitas pajak tangguhan $\left(t_{\text {hitung }}-0,176<t_{\text {tabel }}=\right.$ 2,008) dan nilai probabilitas lebih kecil dari 0,05 (sig,t 0,8611 <0,05) sehingga dapat disimpulkan $\mathrm{H}_{02}$ diterima yang berarti bahwa liabilitas pajak tangguhan tidak berpengaruh signifikan secara parsial terhadap manajemen laba. Ketika liabilitas pajak tangguhan banyak maka perusahaan akan memiliki kewajiban yang tinggi karena perusahaan harus membayar kewajiban tersebut, yang menyebabkan berkurangnya laba. Pajak tangguhan terjadi karena perbedaan antara Standar Akuntansi Keuangan (SAK) dan ketentuan Peraturan Perpajakan, secara umum ada juga perbedaan antara pendapatan sebelum pajak menurut pembukuan dan pendapatan kena pajak. Dengan demikian, akan ada pula perbedaan antara beban pajak dan hutang pajak (hutang pajak penghasilan)

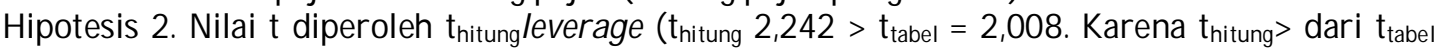
(thitung 2,242) dan nilai probabilitas lebih besar dari 0,05 (sig,t 0,03<0,05) sehingga dapat disimpulkan $\mathrm{H}_{03}$ ditolak yang berarti bahwa leverage berpengaruh signifikan secara parsial terhadap manajemen laba. Ketika utang perusahaan banyak maka perusahaan akan memiliki resiko bisnis yang tinggi karena perusahaan terancam tidak dapat memenuhi membayar hutang tersebut. Didalam perusahaan utang digunakan untuk investasi seperti membeli mesin, kendaraan. Tujuan perusahaan melakukan manajemen laba yaitu untuk menunjukan kepada investor maupun kerditor mengenai hasil investigasi yang menguntungkan. Investasi itu menguntungkan tampak dari laba yang besar, supaya labanya tampak lebih besar maka manajer melakukan manajemen laba dengan cara menaikan laba.

\section{KESIMPULAN}

\section{Kesimpulan}

Penelitian ini bertujuan untuk membuktikan pengaruh liabilitas pajak tangguhan, dan leverage terhadap manajemen laba pada perusahaan LQ45 di Bursa Efek Indonesia periode 2014-2018. Hasil studi menunjukkan bahwa liabilitas pajak tangguhan tidak signifikan mempengaruhi manajemen laba, sedangkan leverage terbukti secara positif dan signifikan mempengaruhi manajemen laba. Temuan ini mengindikasikan bahwa para investor dapat menjadikan leverage sebagai faktor yang dapat menjelaskan perilaku manajemen laba yang dilakukan oleh perusahaan. Investor menggunakan leverage untuk secara signifikan meningkatkan return yang dapat diberikan pada investasi. Mereka meningkatkan investasi mereka dengan menggunakan berbagai instrumen pembiayaan. Di sisi lain, perusahaan dapat menggunakan leverage untuk membiayai operasional dan kegiatan bisnis mereka. 


\section{Keterbatasan}

Penelitian ini memiliki beberapa keterbatasan, diantaranya adalah: minimnya periode pengamatan dan jumlah perusahaan yang diobservasi. Studi berikutnya perlu memperpanjang periode pengamatan (misalnya 10 tahun). Selain itu, pajak tangguhan tidak signifikan mempengaruhi manajemen laba dan hasil ini berbeda dengan beberapa studi sebelumnya. Perlu dilakukan pengujian ulang ulang untuk memverifikasi hubungan antara dua variabel tersebut.

\section{REFERENSI}

Anasta, L. (2015). Analisa Pengaruh Deferred Tax Asset, Deferred Tax Liabilities, dan Tingkat Hutang Terhadap Manajemen Laba Pada Perusahaan Sub Sektor Industri Makanan dan Minuman di Indonesia. Jurnal Tekun, 4(02), 250-270.

Mulatsih, S. N., Dharmayanti, N., \& Ratnasari, A. (2019). The Effect of Tax Planning, Asset of Deferred Tax, Deferred Tax Expense on Profit Management (Case Study of Manufacturing Companies Listed on the Stock Exchange 2013-2017 Period). KnE Social Sciences, 933-947.

Junery, V. (2016).Pengaruh Beban Pajak Tangguhan, Bebean Pajak Kini dan Kompensasi Manajemen Terhadap Manajemen Laba, JOM Fekon, 13 (01).

Octaviani, S., \& Kartikaningdyah, E. (2019). Effect Of Corporate Governance (Woman's Executive Board), Company Size And Leverage On Profit Management. Journal Of Applied Managerial Accounting, 3(1), 51-65.

Puspitasari, D. P., \& Murdiati, S. (2018). Pengaruh Pajak Tangguhan, Perencanaan Pajak dan Asset Perusahaan Terhadap Manajemen Laba Pada Perusahaan Kimia yang Terdaftar di Bursa Efek Indonesia Tahun 2013-2017. PERMANA, 10(1).

Puspitasari, N., \& Trisnawati, R. (2016). Pengaruh Asimetri Informasi, Leverage Dan Profitabilitas Terhadap Manajemen Laba Riil (Studi Empiris Pada Perusahaan Manufaktur Yang Terdaftar Di Indeks Lq-45 Dan Jii Periode 2004-2013) (Doctoral dissertation, Universitas Muhammadiyah Surakarta).

Situmorang, B. (2019, December). Detection of Profit Management Practices through Deferred Tax Expenses that are moderated by Tax Planning Practices. In 1st International Conference on Applied Economics and Social Science (ICAESS 2019). Atlantis Press.

Sulistyanto, H. S, (2014), Manajemen Laba : Teori dan Model Empiris, Edisi Kedua. Jakarta: Penerbit Grasindo.

Susanto, Y. K., Pirzada, K., \& Adrianne, S. (2019). Is tax aggressiveness an indicator of earnings management?. Polish Journal of Management Studies, 20.

Sutadipraja, M. W., Ningsih, S. S., \& Mardiana, M. (2019). Pajak Kini, Pajak Tangguhan, Aset Pajak Tangguhan, Liabilitas Pajak Tangguhan Terhadap Manajemen Laba. Reviu Akuntansi dan Bisnis Indonesia, 3(2), 149-162.

Wang, Y., Butterfield, S., \& Campbell, M. (2016). Deferred tax items as earnings management indicators. International Management Review, 12(2), 37-42.

Whelan, J. and Demangeot, C. (2015). Signaling Theory. In Wiley Encyclopedia of Management (eds C.L. Cooper, N. Lee and A.M. Farrell). doi:10.1002/ 9781118785317.weom090243

Widarti, S., \& Pramajaya, J. (2018). The Effect Of Profit Management On Company Performance. International Journal of Academic Research in Economics and Management Sciences, 7(4), 44-63

Widiatmoko, J., \& Mayangsari, I. (2016). The impact of deferred tax assets, discretionary accrual, leverage, company size and tax planning onearnings management practices.JDM (Jurnal Dinamika Manajemen), 7(1), 22-31.

\section{PROFIL PENULIS}

Eky Septiawan dan Yohan H. Wibowo adalah mahasiswa dan dosen di Fakultas Ekonomi Universitas Islam Attahiriyah, Jakarta, Indonesia. Hendryadi adalah dosen prodi manajemen di Sekolah Tinggi Ilmu Ekonomi Indonesia Jakarta, Jakarta, Indonesia 
AKURASI: Jurnal Riset Akuntansi dan Keuangan, Vol 2, No.2, Agustus 2020, pp. 95 - 102 eISSN: 2685-2888

Journal homepage: https:/ / ejournal.imperiuminstitute.org/ index.php/ AKURASI 